\title{
Ecto- and Endoparasitic Fungi on Ants from the Holarctic Region
}

\author{
Xavier Espadaler ${ }^{1}$ and Sergi Santamaria ${ }^{2}$ \\ ${ }^{1}$ Ecology Unit and CREAF, Autonomous University of Barcelona, 08193 Bellaterra, Spain \\ ${ }^{2}$ Botany Unit, Autonomous University of Barcelona, 08193 Bellaterra, Spain \\ Correspondence should be addressed to Xavier Espadaler, xavier.espadaler@uab.es
}

Received 19 August 2011; Accepted 25 September 2011

Academic Editor: Alain Lenoir

Copyright ( 2012 X. Espadaler and S. Santamaria. This is an open access article distributed under the Creative Commons Attribution License, which permits unrestricted use, distribution, and reproduction in any medium, provided the original work is properly cited.

The ant-specific fungi Aegeritella, Laboulbenia, Rickia, Hormiscium, and Myrmicinosporidium in the Holarctic region-nine species-are reviewed. Present knowledge is highly biased geographically, as shows the single record for Holarctic Asia, and this is to solve. The phylogenetic position of Aegeritella, Hormiscium, and Myrmicinosporidium is unknown. Hosts seem to be also skewed phylogenetically although this may be a true pattern.

\section{Introduction}

Extensive, massive mycoses are an extremely rare instance in ants [1] and involve individuals, rather than whole colonies. A fortiori, documented population level attacks are practically nonexistent. A case concerning Tetramorium caespitum $[2,3]$ seems to be an isolate within ant literature. Here we deal with ecto- and endoparasitic fungi, and we limit our survey to those that are ant specific. We differentiate parasitic fungi, that are not deadly to ants, and pathogenic fungi, which kill the host. Thus, generalist entomopathogenic fungi like Beauveria and Metarhizium or ant specifics like Pandora myrmecophaga (Figure 1) or Telohannia solenopsae are not included. Recent revisions of entomopathogens are those from Roy et al. [4], Kleespies et al. [5], Oi and Pereira [6] and, centred in social insects, in the seminal book by SchmidHempel [7]. We aim to review the knowledge of taxonomic and geographic distribution and, whenever possible, natural history and/or ecology of selected groups of fungi. The Holarctic is understood as comprising the nontropical parts of Europe and Asia, Africa north of the Sahara, and North America south to the Mexican desert region.

The fungi considered in this paper show a gradient of negative effects on the host. From a seemingly near absolute absence of any measurable-or measured-effect in some cases (Aegeritella, Hormiscium, and Laboulbenia camponoti), to a mild effect in other Laboulbeniales (reduced immunological response in L. formicarum; S. Cremer pers. comm.), or a possible strong negative effect in Myrmicinosporidium). This effect may concern exclusively infested individual ants (Myrmicinosporidium) although in some cases, because of the fungus life cycle and the social nature of ants, with many physical contacts between colony members outside of the nest and in the nest galleries, this may be multiplied and traduced directly to the colony level (Laboulbeniales, or Aegeritella). This general absence of strong negative effects indicates probably a very old interaction with ants.

An unfortunate circumstance is the completely unknown phylogenetic position of some of those specific ant fungi, and this is calling for a dedicated, focused study, using molecular techniques. We stress the necessity of enhanced attention from the part of myrmecologists and mycologists towards this interesting group of ectoparasitic fungi. Just remembering their existence, and with a little care and open mind, many more instances of Laboulbeniales, Aegeritella, Myrmicinosporidium, and pathogenic fungi on ants should surface in ample areas within the Holarctic region.

\section{Material and Methods}

Apart from our current files, we did a search in the ant data base FORMIS (version 2011) [9]. Search terms are as follow: ectoparasitic, endoparasitic, fungus, fungi, Laboulbeniales, Laboulbenia, Rickia, Aegeritella, Myrmicinosporidium, and filtered out a posteriori by geographical region 


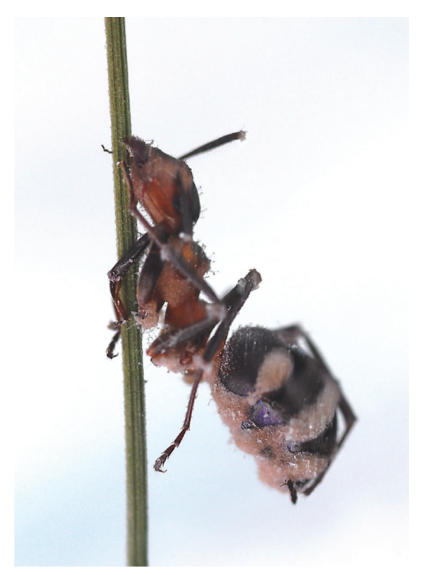

Figure 1: Pandora myrmecophaga having killed a worker Formica rufa, from The Netherlands, showing the characteristic attachment to the distal part of a grass leave caused by the summit disease [after [8]; Photo by H. Niesen; with permission).

(Holarctic). Within each fungus species, we give the country, ant species attacked, and reference. Taxonomical scheme and terminology follow Index Fungorum [10] (http://www.indexfungorum.org/).

\section{Results}

\subsection{Ectoparasitic Fungi on Ants}

3.1.1. Aegeritella Bałazy \& J. Wiśn. Anamorphic Pezizomycotina. Those fungi were first noted by Wiśniewski in 1967 [11] although its fungal nature was not proven then. The fungi grow over the cuticle like dark protuberances (= bulbils). On a first sight, they look like dirt, and its form is usually a dome, rounded in perimeter, and up to $400 \mu \mathrm{m}$ diameter (Figure 2). The number of bulbils may be from a single one to several hundreds. The distribution of bulbils on the body of ants is heterogeneous, being more abundant at the rear part [12-14]. The total number of bulbils is inversely related to ant size, with bigger ants having less bulbils than smaller ants [14]. Bulbils have been detected in workers and queens.

The ant-fungus relationship has not been properly ascertained although a reduced life duration or activity level has been suggested $[15,16]$. In a similar vein, Bałazy et al. [17] note some workers with hundreds of bulbils, having immobilized bucal palps, all covered by hyphae. Nothing is known of the dynamics of infestation or transmission mechanisms of those enigmatic fungi, not even its phylogenetic position within the realm of Fungi.

(1) Aegeritella superficialis Bałazy \& J. Wiś. 1974.

\section{Europe}

Czech Republic: Formica sanguinea Latreille, Formica rufa L., Formica polyctena Förster, Formica pratensis Retzius, Formica truncorum Fabricius, Formica lugubris Zetterstedt, Formica exsecta Nylander [18, 19].
Germany: Formica polyctena Förster [16].

Italy: Formica lugubris Zetterstedt [20].

Poland: Formica polyctena Förster, Formica rufa L., Formica pratensis Retzius; Formica truncorum Fabricius, Formica fusca L. [21-24]; Formica sanguinea Latreille [25].

Rumania: Formica rufa group [26].

Spain: Formica decipiens Bondroit [12].

Switzerland: Formica rufa L., Formica polyctena Förster, Formica lugubris Zetterstedt, Formica sanguinea Latreille [15].

(2) Aegeritella tuberculata Bałazy \& J. Wiś. 1983.

Europe

Czech Republic: Lasius distinguendus Emery, Lasius nitidigaster Seifert (as Lasius rabaudi), Lasius umbratus (Nylander) [19].

Poland: Lasius flavus (Fabricius), Formica fusca L. [27].

Spain: Lasius umbratus (Nylander), Lasius distinguendus (Emery) [28], Lasius umbratus ([29], as L. distinguendus); Formica pressilabris Nylander [12]; Formica rufa L., Formica rufibarbis Fabr. [14]. Canary islands: Tenerife, Lasius grandis Forel [13].

North America

USA, Alaska: Lasius pallitarsis (Provancher) ([30], as Lasius sitkaensis).

(3) Aegeritella roussillonensis Bałazy, Lenoir \& J. Wiś. 1986.

France. On Cataglyphis cursor (Fonscolombe) [17].

(4) Aegeritella maroccana Bałazy, Espad. \& J. Wiś. 1990.

Morocco. On Aphaenogaster baronii Cagniant [31].

(5) An unidentified Aegeritella was noted on two workers

Polyergus breviceps Emery from Arizona [30].

\subsubsection{Hormiscium Kunze, Incertae Sedis Pezizomycotina}

(1) Hormiscium myrmecophilum Thaxter, 1914.

The species was described from an Amazonian Pseudomyrmex and remained elusive since its original description until it was found in Europe eighty years later. The filamentous, somewhat dichotomic thallus is undifferentiated and grows directly out of different parts of the ant body, without any apparent attaching structure. Mycelia have a maximum length of $163 \mu \mathrm{m}$ and constant width of $10 \mu \mathrm{m}$. (Figure 3). Spores are unknown. 


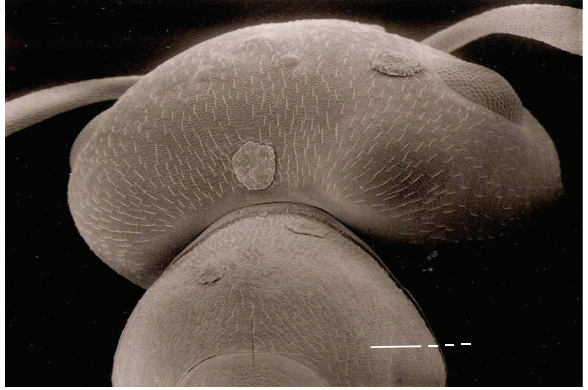

(a)

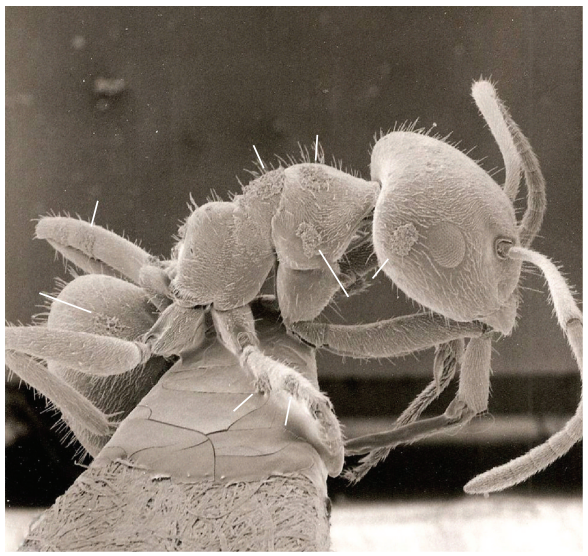

(c)

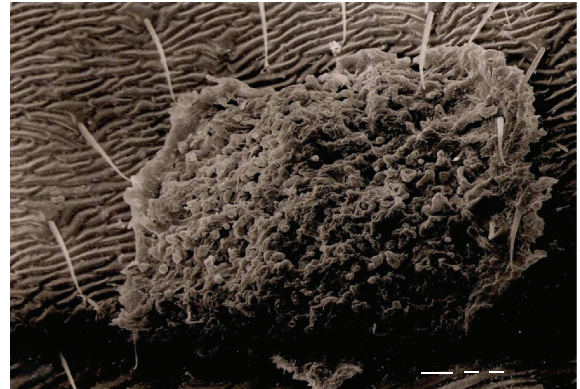

(b)

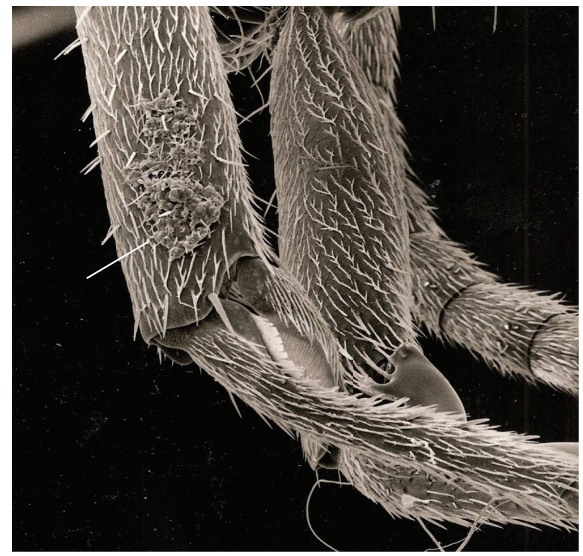

(d)

Figure 2: (a) Aegeritella tuberculata on Formica pressilabris (Spain). Two bulbils are in the pronotum, one at the back of head, (b) closeup of a bulbil; (c) A. tuberculata on Lasius grandis from Tenerife, Canary Islands; white arrows indicate bulbils; (d) closeup of bulbils in the first leg.

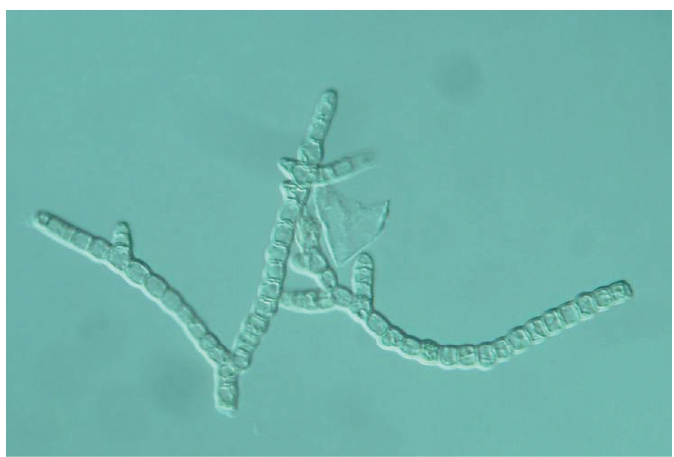

(a)

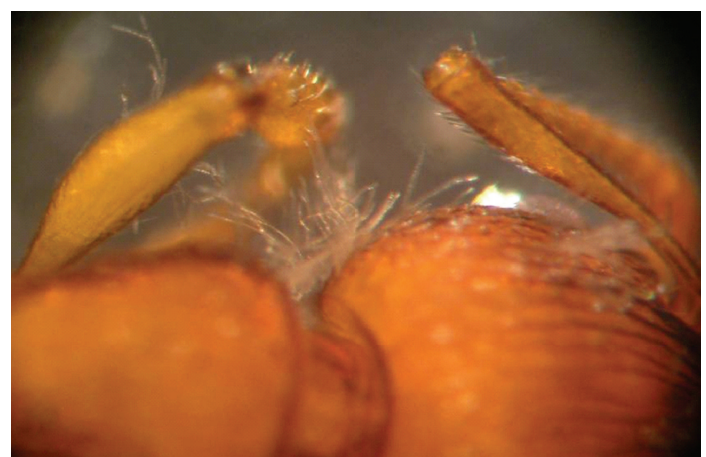

(b)

Figure 3: Hormiscium myrmecophilum. (a) hyphae on Myrmica sp.; (b) worker Myrmica sabuleti with hyphae on the head and lateral pronotum.

Europe

Portugal. On Myrmica sp. [32].

Spain. On Myrmica sabuleti Meinert (present paper).

3.1.3. Laboulbeniales (Ascomycota). Laboulbeniales are unusual among fungi because of their limited thallus with determinate growth. They are obligate external parasites of arthropods, especially insects. One key peculiarity is the ability to grow on their hosts without inflicting any noticeable injury. Ten orders of insects, in addition with millipedes and acari, may be affected although $80 \%$ of some 2000 species are recorded from beetles [33]. Only six are known to date infesting ants from the Holarctic region, and all castes are known to be susceptible to infestation.

(1) Rickia wasmannii Cavara, 1899.

The species is extremely characteristic in its microscopic morphological aspect (Figure 4) and is limited to several 


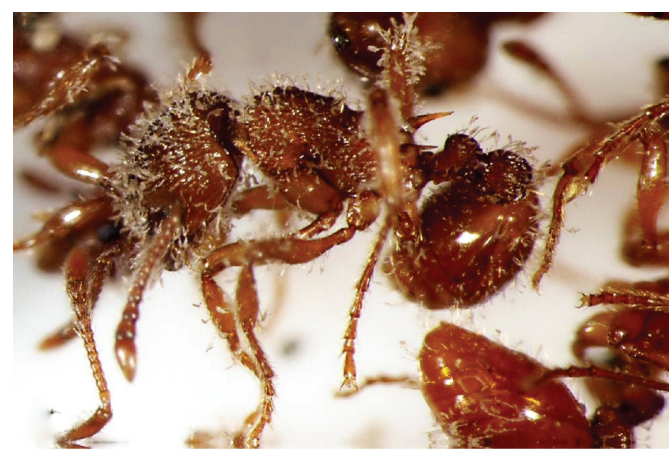

(a)

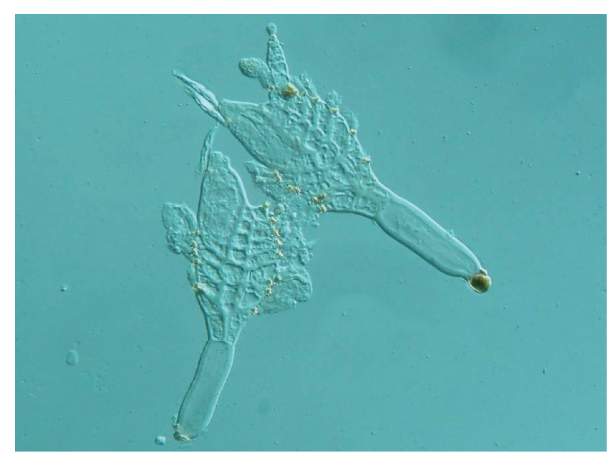

(b)

Figure 4: (a) Rickia wasmannii on Myrmica scabrinodis from Slovakia. Each “spatulate hair” is a thallus of Rickia. Photo by P. Bezděčka; with permission; (b) two mature thalli. Spores are oozing out of the perithecium on the specimen from the right.

species of Myrmica. Infested ants may harbour from a few thalli to several hundred thalli all over the body. Heavy infestations are visible to the naked eye and give a greyish shade, a pulverulent image to living individuals. Worker and queens may be infested.

\section{Europe}

Austria: Myrmica rubra (L.) [34].

Bulgaria: Myrmica scabrinodis Nylander [35].

Czech Republic: Myrmica slovaca Sadil, Myrmica scabrinodis Nylander [36].

France: Myrmica scabrinodis (Nylander) [37].

Germany: Myrmica rubra (L.) [38].

Hungary: Myrmica slovaca Sadil (as M. salina), M. scabrinodis Nylander, M. specioides Nylander, M. vandeli Bondroit [39].

Italy: Myrmica scabrinodis Nylander [40].

Luxembourg: Myrmica rubra L. [41].

Rumania: Myrmica scabrinodis Nylander [39].

Slovakia: Myrmica scabrinodis Nylander [42].

Slovenia: Myrmica sabuleti [41].

Spain: Myrmica specioides Bondroit [28, 43]; Myrmica spinosior Bondroit ([43], as M. sabuleti).

Switzerland: Myrmica rubra (L.) ([44], as M. laevinodis).

United Kingdom: Myrmica sabuleti Meinert [45, 46].

(2) Rickia sp.1.

Greece: On Messor (unpublished observation: description is pending).

(3) Laboulbenia camponoti S. W. T. Batra 1963.

Under the binocular, the thallus looks like a distorted ant hair (Figure 5) and is found all over the body, albeit more abundant in dorsal surfaces and external surface of legs.
Density is much lower than in other ant-specific Laboulbeniales. In the Holarctic, it has been detected exclusively in Camponotus species, all six from the subgenus Tanaemyrmex.

Asia

Turkey: Camponotus baldaccii Emery [47].

Europe

Bulgaria: Camponotus aethiops (Latreille), Camponotus universitatis Forel, Camponotus sp. (as C. pilicornis) [35].

Spain: Camponotus pilicornis (Roger) [48]; Camponotus sylvaticus (Olivier) [49].

(4) Laboulbenia formicarum Thaxt, 1902.

This is one of the smallest Laboulbeniales (up to $0.3 \mathrm{~mm}$ total length). Thalli can be extremely abundant on infested workers (Figure 6), which go foraging seemingly unaffected amid noninfested workers.

\section{North America}

Canada: Lasius alienus (Förster) [50].

USA: Formica argentea Wheeler [51]; Formica aserva Forel ([52], as F. subnuda); Formica curiosa Creighton ([53], as F. parcipappa); Formica incerta Buren [51]; Formica lasioides Emery [54]; Formica montana Wheeler ([54], as F. neocinerea); Formica neogagates Viereck [51, 55]; Formica pallidefulva Latreille ([54], as F. nitidiventris; [56], as F. schaufussi); Formica puberula Emery [52]; Formica subintegra Wheler [54]; Formica subpolita Mayr ([52], as F. camponoticeps); Formica subsericea Say [54]; Formica vinculans Wheeler [54]; Lasius alienus (Förster) ([55, 57], as L. americanus); Lasius murphyi Forel [58]; Lasius neoniger Emery [51, 59]; Lasius pallitarsis (Provancher) ([30], as L. sitkaensis); Myrmecocystus mimicus Wheeler [60]; Polyergus breviceps Emery [54]; Polyergus lucidus Mayr [54]; Prenolepis impairs (Say) [54]. 


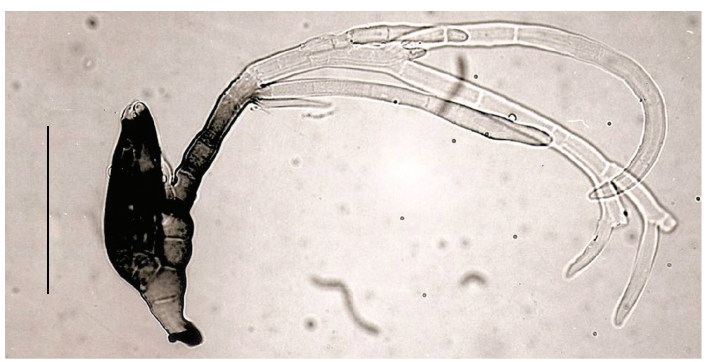

(a)

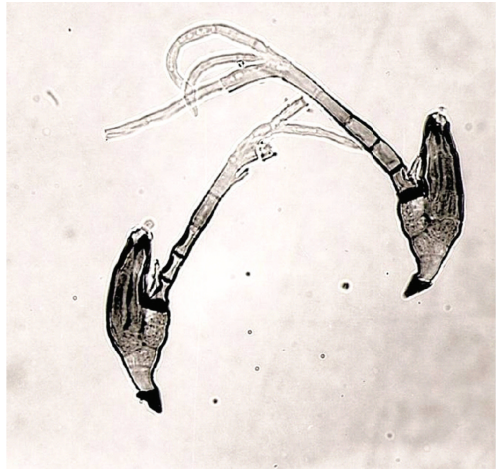

(b)

FIGURE 5: Laboulbenia camponoti from Camponotus sylvaticus (Spain); line: $1 \mathrm{~mm}$. (a) A mature specimen; (b) two immature specimens.

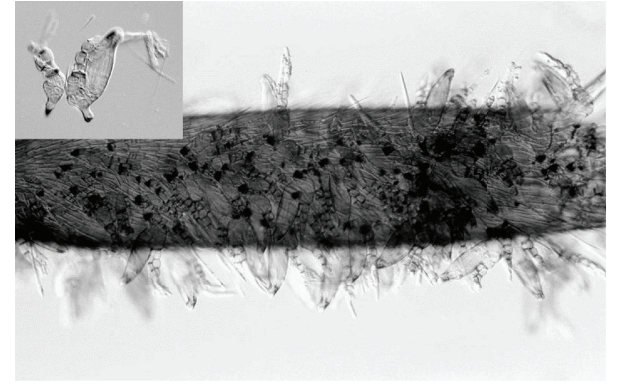

FIGURE 6: Laboulbenia formicarum on Lasius grandis. Worker tibia, showing full-grown thalli and dark spots which indicate attachment point of spores (more than 50 in the viewed side). Inset: one mature (right) and immature (left) specimens of Laboulbenia formicarum.

Europe

France: Lasius neglectus Van Loon, Boomsma \& Andrásfalvy [61].

Portugal (Madeira): Lasius grandis Forel [62].

Spain: Lasius neglectus Van Loon, Boomsma \& Andrásfalvy [63].

\subsection{Endoparasitic Fungi on Ants}

\subsubsection{Incertae Sedis}

Myrmicinosporidium durum Hölldobler 1933. Those fungi were first noted by Hölldobler $[64,65]$ although they were formally described later, in 1933 [66]. Its phylogenetic position is still unknown, and their true fungal nature has been only proved recently [67]. Infested ants are usually well detected because the darker spores are visible through the integument (Figure 7); spores number may be very low, but usually they reach more than one hundred in a single ant. The caveat here is that the fungus may be much difficult to detect in ants having fuscous or black colouration. As a consequence, host range is probably biased. The usual aspect of concave spores, with a bow-like depression, is an artefact of fixation in alcohol [68].
Although the infested workers are almost certainly killed by the fungus when spores begin producing hyphae, life span seems not to be curtailed [67]. Infested workers seem scarcely affected in its normal behaviour $[67,69]$, and infested queens may participate in swarming flights [69] and show normal fertility [68]. Males have been found infected too [70]. Life cycle and mode on infestation are unknown although reports of Myrmicinosporidium from callow workers in Pogonomyrmex badius indicate that the infection is carried over from immature stages [71]. It is perhaps significant that the majority of diseased ants were collected in late summer and fall. After hibernation, those infected workers die [69]. Its geographical distribution is ample as is also the range of hosts.

\section{Europe}

Austria: Plagiolepis vindobonensis Lomnicki [67].

Croatia: Temnothorax recedens (Nylander), Temnothorax affinis (Mayr), Temnothorax unifasciatus (Latreille), Plagiolepis pygmaea (Latreille) [67].

France: Solenopsis fugax (Latreille), Pheidole pallidula (Nylander) [72]; Temnothorax unifasciatus (Latreille), Temnothorax recedens (Nylander) [68].

Germany: Solenopsis fugax (Latreille) $[64,65]$ ), Temnothorax tuberum (Fabricius) [66].

Hungary: Solenopsis fugax (Latreille), Tetramorium caespitum (L.), Plagiolepis taurica Santschi [73].

Italy: Temnothorax unifasciatus (Latreille) [67, 69], Temnothorax albipennis (Curtis) [67], Temnothorax angustulus (Nylander) [67], Temnothorax exilis (Emery) [67], Temnothorax nylanderi (Forster) [67], Chalepoxenus muellerianus (Finzi) [67].

Spain: Pheidole pallidula (Nylander), Solenopsis sp., Strongylognathus caeciliae Forel, Tetramorium semilaeve (André), Plagiolepis pygmaea (Latreille) [70], Temnothorax lichtensteini (Bondroit), Temnothorax racovitzai (Bondroit) [72].

Switzerland: Solenopsis fugax (Latreille) [68]. 


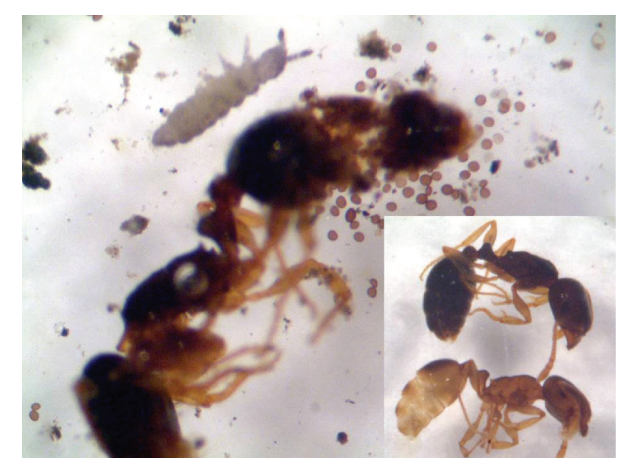

(a)

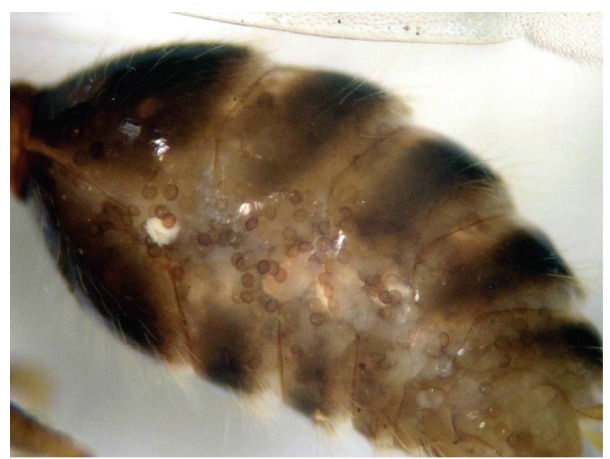

(c)

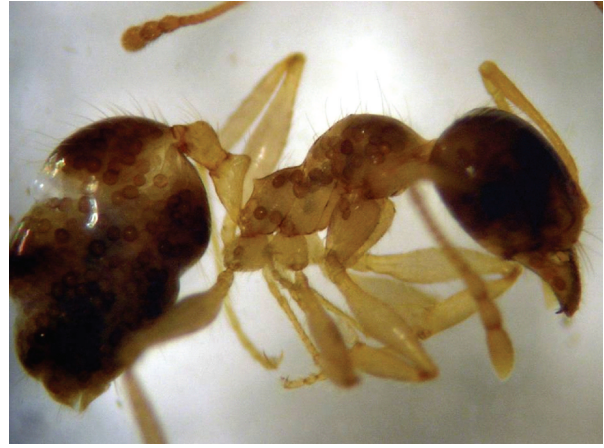

(b)

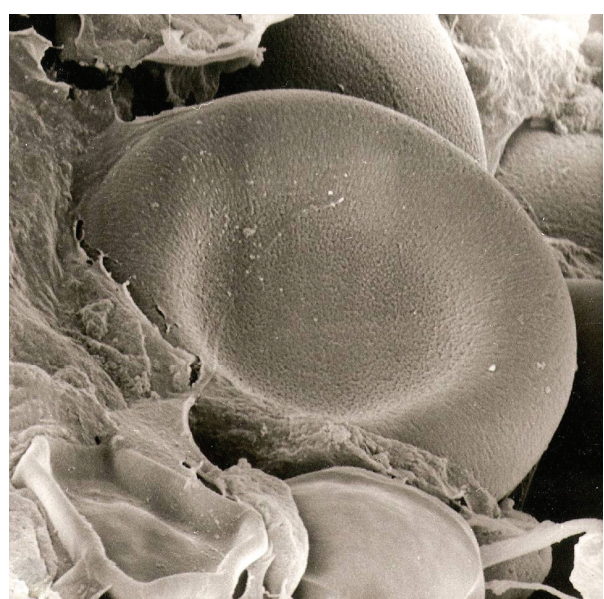

(d)

Figure 7: (a) Myrmicinosporidium mature spores inside workers Tetramorium semilaeve (inset: darker, infested worker, and normally coloured worker); (b) Pheidole pallidula with many spores on thorax, coxae, and gaster; (c) gaster of a male Pheidole pallidula with spores; (d) SEM image of a spore, showing the artifactual characteristic doughnout shaped form resulting from the alcohol fixation.

\section{North America}

USA: Pogonomyrmex barbatus (F. Smith) [67]; Solenopsis carolinensis Forel, Solenopsis invicta Buren, Pheidole tysoni Forel, Pheidole bicarinata Mayr, Pyramica membranifera (Emery), Pogonomyrmex badius (Latreille) [67]; Nylanderia vividula (Nylander) ([67], as Paratrechina vividula).

3.2.2. Dubious Cases. Across literature, two cases have been described but not identified. Although unproven, those are highly likely to belong in Aegeritella because of the macroscopic description given.

Bequaert ([56], page 74) wrote "A number of so-called "imperfect fungi"-incompletely developed, conidia-bearing or sterile stages of various Ascomycetes-have been recorded from ants. A nest of Formica rufa Linné, at Potsdam, Germany, was heavily infested with fungous growths, about the size of a pinhead and attached mainly to the thorax, more rarely to other parts of the body. The ants were apparently but little hampered by their parasites. From cultures obtained with these fungi, Bischoff concluded that thy belonged to several species, among them a Mucor, $a$ Penicillium and a yeast. Thaxter also found in the vicinity of Cambridge, Mass., a fungus forming blackish incrustations on various parts of ants and giving rise to a few short, colorless, erect branches; the exact nature of this plant has not been determined, nor is the name of its host mentioned."

Donisthorpe ([74], page 235 and Figure 86) commenting on Lasius umbratus var. mixto-umbratus Forel, [now Lasius (Chthonolasius) unrecognisable species] noted "On August 11th, 1912, when at Weybridge in company with Professor Wheeler, we found two colonies of this variety, very many of the ants of both being infested with a curious dark brown warty growth in patches on parts of the body and legs-this Wheeler thought might be a fungus which was unknown to him. I kept a number of these ants in captivity, and added uninfected workers of umbrata from other localities; the growth however did not increase nor spread to the new ants, but rather seemed to decrease. I sent some of the infested ants alive and others in spirit, to Dr. Baylis Elliot, and she considered the patches were colonies of unicellular organisms growing on the outside of the ants; eventually she came to the conclusion that they were not fungoid growths, but probably colonies of an alga." Thus, albeit without a named host, Aegeritella is probably present too in the United Kingdom. A search with Donisthorpe's collection and/or in the vicinities of Weybridge could confirm this. 


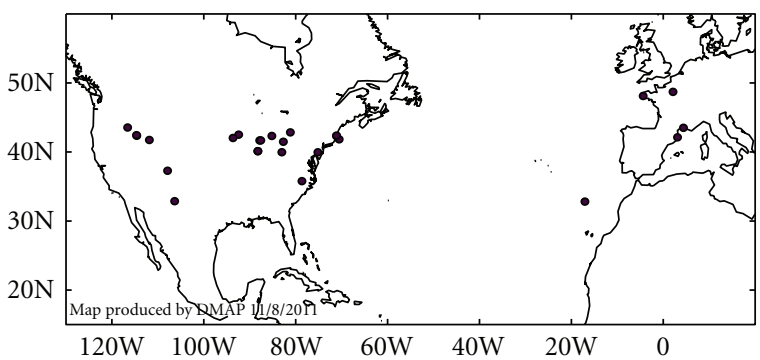

FIgURE 8: Distribution of Laboulbenia formicarum. North American records date from 1902 to 1979 and belong in 24 ant host species of five genera. European records date from 2003 to 2011 and imply two host species of Lasius.

\section{Discussion}

4.1. On Fungus Taxonomy. Laboulbeniales are taxonomically and nomenclaturally stable. There seems to be no major problem in morphological identification of the species involved. Perhaps, only, it would be worth examining the possibility of several species within Laboulbenia formicarum since its hosts belong in five genera, from three tribesFormicini, Lasiini, and Plagiolepidini-in Formicinae.

Aegeritella is an especially difficult situation. Apart from its doubtful position within Fungi, bulbils are usually not in a perfect fruiting condition, and microscopic preparations are not easy to do since the bulbils are tightly attached to the ant's surface, anchored by the pubescence and hairs of the ant. The two most abundant species (A. superficialis, A. tuberculata) are well differentiated by the presence of hyphal elements in A. superficialis and by its absence in A. tuberculata [17].

Myrmicinosporidium is also an unsolved problem. All records but one are based simply on the presence of spores, which have a strikingly similar appearance across the two continents. Although they seem to be close to Chytridiomycetes [67], it remains to be studied where do those fungi belong within the phylogeny, and also the conspecificity of all so-called M. durum records. A similar situation is that of Hormiscium, from which only hyphae are known.

4.2. Host Phylogeny. A minimum of 13 subfamilies of ants are found in the Holarctic region. Only two (Myrmicinae and Formicinae) are noted with ecto- or endoparasitic fungi. Why should the distribution be so biased? If this is not a sampling artefact, it is noteworthy that the two subfamilies appear close together in the last comprehensive ant phylogenies $[75,76]$, thus indicating perhaps an ancestral susceptibility for both subfamilies.

Aegeritella is found on Formica and Lasius. Laboulbenia species infest exclusively ants from the subfamily Formicinae and Rickia infests Myrmicinae. This host specificity is not rare with Laboulbeniales [33]. Inasmuch L. formicarum is hosted by 24 ant species that belong in three tribes (Formicini, Lasiini, and Plagiolepidini), this calls for a dedicated evaluation (molecular and morphological) of the cospecificity of all populations of $L$. formicarum.
Myrmicinosporidium may be found in both ant subfamilies although the majority of cases belong in the Myrmicinae. We may speculate if the generic name is entirely appropriate or there is a detection bias of unknown origin towards Myrmicinae. Infested species belong in six tribes in Myrmicinae (Dacetini, Formicoxenini, Myrmicini, Pheidolini, Solenopsidini, and Tetramoriini), and one tribe in Formicinae (Plagiolepidini), widely scattered within ant phylogeny ([75], Figure 1; [76], Figure 1). Specificity is evidently not to uncritically assume in this fungus.

4.3. Geographical Distribution and Host Number. Knowledge is absolutely fragmentary and skewed. Asia in special, with a single record of ecto- and endoparasitic fungi, is a promising region to explore. The genus Myrmica with its many species should be searched for Rickia, and the genera Formica and Lasius for Aegeritella. Within Europe, countries such as Ireland, Belgium, The Netherlands, Denmark, Poland, or Portugal are obvious candidates for Rickia. The northernmost locale for Rickia seems to be Denbies Hillside, at $51^{\circ} 14^{\prime} \mathrm{N}$ [45]. Some cases, such as Laboulbenia formicarum (Figure 8) or Myrmicinosporidium durum (Figure 9) agree with the usual worldwide or wide-ranging specific distribution of fungi although others are only known from its original description, from a single locality (Aegeritella maroccana, Aegeritella roussillonensis).

With host number, the situation seems to be dichotomous. Some fungi are known from a range of hosts: $A$. superficialis 9 hosts, A. tuberculata 10, L. formicarum 24, L. camponoti 7, R. wasmannii 8, and Myrmicinosporidium 27, while other fungi are known from single hosts, in parallel with geographical range, likely reflecting a sampling artefact. Horizontal transmission to slave-making ants is possible, as attested by Aegeritella [30] and Laboulbenia formicarum [54] on Polyergus, and by Myrmicinosporidium in Chalepoxenus [67] and Strongylognathus [70].

In the USA, three species (Pheidole, and 2 Solenopsis) from a single farm in Houston Co., Alabama [71] were noted as infested with Myrmicinoporidium. In southern Hungary, three genera (Plagiolepis, Solenopsis, and Tetramorium) [73] were noted as hosts in a single locality. A similar situation is that of an organic citrus field in Spain [70], in which up to four different genera (Pheidole, Plagiolepis, Tetramorium, and Solenopsis) have been detected as hosts during several years, their nests being at distances of 5-20 m. The disease may qualify as chronic in the three localities. In this last locality, Aegeritella on Formica rufibarbis and Laboulbenia camponoti on Camponotus aethiops, C. pilicornis, and C. sylvaticus exist too. The single circumstance we can suggest for this "abnormal" abundance of parasitic fungi in this last site is the intensity—monthly samples—and duration—since 2002 and ongoing - of ecological studies with abundant insect collection. This is suggestive of a general low-prevalence but ample geographic distribution. Thus, we cannot but expect a growth of information if proper attention is directed to those ecto- and endoparasitic fungi of ants. Myrmecologists, please, be aware! 


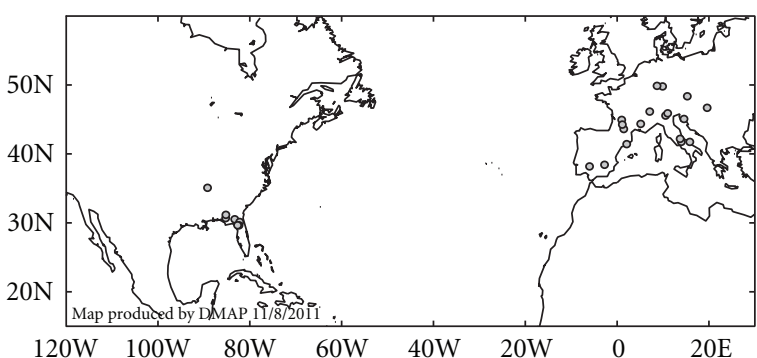

FIgURE 9: Distribution of Myrmicinosporidium sp. Eight ant host species are known from USA, and 19 from Europe.

\section{Acknowledgments}

The authors are grateful to L. Gallé and O. Kanizsai (Hungary) for help with references and unpublished information. They give their thanks to P. Bezděcka for allowing us to use the Rickia wasmannii image and to P. Boer and H. Niesen for the image Formica rufa infested with Pandora myrmecophaga. This work has been supported by Grants from MCYT-FEDER (CGL2004-05240-C02-01/BOS, CGL2007-64080-C02-01/BOS, and CGL2010-18182).

\section{References}

[1] B. Hölldobler and E. O. Wilson, The Ants, Springer, Berlin, Germany, 1990.

[2] P. I. Marikovsky, "On some features of behavior of the ants Formica rufa L. infected with fungous disease," Insectes Sociaux, vol. 9, no. 2, pp. 173-179, 1962.

[3] O. L. Rudakov, "Mikoz murav'ev (Predvant scobshchenie)," Sb. Entomol. Rabot A kad. Nauk Kirghizsk. SSR, Kirghizsk. Otd. Vses. Entomol. Obshch, vol. I, pp. 128-130, 1962.

[4] H. E. Roy, D. C. Steinkraus, J. Eilenberg, A. E. Hajek, and J. K. Pell, "Bizarre interactions and endgames: entomopathogenic fungi and their arthropod hosts," Annual Review of Entomology, vol. 51, pp. 331-357, 2006.

[5] R. G. Kleespies, A. M. Huger, and G. Zimmermann, "Diseases of insects and other arthropods: results of diagnostic research over 55 years," Biocontrol Science and Technology, vol. 18, no. 5, pp. 439-484, 2008.

[6] D. H. Oi and R. M. Pereira, "Ant behavior and microbial pathogens (Hymenoptera: Formicidae)," Florida Entomologist, vol. 76, pp. 63-74, 1993.

[7] P. Schmid-Hempel, Parasites in Social Insects, Princeton University Press, Princeton, NJ, USA, 1998.

[8] P. Boer, "Observations of summit disease in Formica rufa Linnaeus, 1761 (Hymenoptera: Formicidae)," Myrmecological News, vol. 11, pp. 63-66, 2008.

[9] D. P. Wojcik and S. D. Porter, "FORMIS: a master bibliography of ant literature," 2011, http://www.ars.usda.gov/saa/cmave/ ifahi/formis.

[10] "Index Fungorum," 2011, http://www.indexfungorum.org/.

[11] J. Wiśniewski, "Narosla zaobserwowane na robotnicach Formica polyctena Forst. (Hym., Formicidae)," Polskie Pismo Entomologiczne, vol. 37, pp. 379-383, 1967.

[12] X. Espadaler and J. Wiśniewski, "Aegeritella superficialis Bał. et Wiś. and A. tuberculata Bał. et Wiś. (Deuteromycetes), epizoic fungi on two Formica (Hymenoptera, Formicidae) species in the Iberian Peninsula," Butlletí de l'Institució Catalana d' Història Natural, vol. 54, pp. 31-35, 1987.

[13] X. Espadaler and P. Oromí, "Aegeritella tuberculata Bałazy et Wiśniewski (Deuteromycetes) found on Lasius grandis (Hymenoptera, Formicidae) in Tenerife, Canary Islands," Vieraea, vol. 26, pp. 93-98, 1998.

[14] X. Espadaler and S. Monteserín, “Aegeritella (Deuteromycetes) on Formica (Hymenoptera, Formicidae) in Spain," Orsis, vol. 18, pp. 13-17, 2003.

[15] D. Chérix, "Note sur la présence d'Aegeritella superficialis Bał. \& Wiś. (Hyphomycetales, Blastosporae) sur des espèces du genre Formica (Hymenoptera, Formicidae) en Suisse," Bulletin de la Societe Entomologique Suisse, vol. 55, pp. 337-379, 1982.

[16] J. Wiśniewski and A. Buschinger, “Aegeritella superficialis Bał. et Wiś., ein epizootischer Pilz bei Waldameisen in der Bundesrepublik Deutschland," Waldhygiene, vol. 14, pp. 139-140, 1982.

[17] S. Bałazy, A. Lenoir, and J. Wiśniewski, “Aegeritella roussillonensis n. sp. (Hyphomycetales, Blastosporae) une espèce nouvelle de champignon epizoique sur les fourmis Cataglyphis cursor (Fonscolombe) (Hymenoptera, Formicidae) en France," Cryptogamie, Mycologie, vol. 7, pp. 37-45, 1986.

[18] P. Bezděčka, "Epizootické houby rodu Aegeritella Bał. et Wiś. (Hyphomycetales, Blastosporae) na mravencích v Československu,” Česká Mykologie, vol. 44, pp. 165-169, 1990.

[19] P. Bezděčka, "Parazitické houby na mravencích rodu Formica," Formica, Zpravodaj Pro Aplikovaný Výzkum a Ochranu Lesních Mravenců (Liberec), vol. 2, pp. 71-75, 1999.

[20] J. Wiśniewski, "Occurrence of fungus Aegeritella superficialis Bał. \& Wiś., 1974, on Formica lugubris Zett. in Italian Alps," Bollettino della Società Entomologica Italiana, vol. 109, pp. 8384, 1977.

[21] S. Bałazy and J. Wiśniewski, "Aegeritella superficialis gen. et sp. nov., epifityczny grzyb na mrowkach z rodzaju Formica L.," Prace Komisji Nauk Rolniczych i Komisji Nauk Lesnych, Poznanskie Towarzystwo Przyjaciol Nauk, Wydzial Nauk Rolniczych $i$ Lesnych, vol. 38, pp. 3-15, 1974.

[22] J. Wiśniewski, "Wystepowanie grzyba Aegeritella superficialis Bał. et Wiś. w Wielkopolskim Parku Narodowym," Prace Poznan Tow Przyjaciol Nauk Wydz Nauk Roln Lesn, vol. 42, pp. 41-45, 1976.

[23] S. Bałazy and J. Wiśniewski, "Aegeritella superficialis Bał. et Wiś. ein epizootischer Pilz auf Ameisen,” Die Waldameise, vol. 2, pp. 49-50, 1989.

[24] J. Wiśniewski, "Aktueller Stand der Forschungen über Ameisen aus der Formica rufa-Gruppe (Hym., Formicidae) in Polen," Bull. SROP / WPRS Bull. OILB, vol. II-3, pp. 285-301, 1979.

[25] J. Wiśniewski and J. Sokolowski, "Nowe stanowiska grzybów Aegeritiella superficialis Bałazy et Wiśniewski i Erynia myrmecophaga (Turian et Wuest) Remaudière et Hennebert na mrówkach w Polsce," Prace Komisji Nauk Rolniczych i Komisji Nauk Lesnych, Poznanskie Towarzystwo Przyjaciol Nauk, Wydzial Nauk Rolniczych i Lesnych, vol. 56, pp. 137-144, 1983.

[26] V. D. Pascovici, "O noua entitate în microflora României: Aegeritella superficialis Bał. et Wiś., 1974 (Hiph., Blastosporae), parazita pe speciile din grupa Formica (Hym., Formicidae)," Revista Padurilor Industria Lemnului, Celuloza si Hirtie; Celuloza si Hirtie, pp. 148-149, 1983.

[27] S. Bałazy and J. Wiśniewski, "A new species of epizoic fungus on ants-Aegeritella tuberculata sp. nov.", Bulletin de l'Academie Polonaise des Sciences Série des Sciences Biologiques, vol. 30, pp. 85-88, 1982. 
[28] X. Espadaler and D. Suñer, "Additions to iberian parasitic insect fungi," Orsis, vol. 4, pp. 145-149, 1989.

[29] F. García, X. Espadaler, P. Echave, and R. Vila, "Hormigas (Hymenoptera, Formicidae) de los acantilados de l'Avenc de Tavertet (Osona)," Boletín de la Sociedad Entomológica Aragonesa, vol. 47, pp. 363-367, 2010.

[30] X. Espadaler and X. Roig, "Aegeritella (Deuteromycetes) associated with ants in America North of Mexico," Sociobiology, vol. 23, pp. 39-43, 1993.

[31] S. Bałazy, X. Espadaler, and J. Wiśniewski, "A new myrmecophilic Hyphomycete, Aegeritella maroccana sp nov.," Mycological Research, vol. 94, pp. 273-275, 1990.

[32] S. Santamaria, "Sobre alguns fongs rars recol-lectats en insects vius," Revista de la Societat Catalana de Micologia, vol. 18, pp. 137-150, 1995.

[33] I. I. Tavares, "Laboulbeniales (Fungi, Ascomycetes)," Mycological Memoirs, vol. 9, pp. 1-627, 1985.

[34] J. Rick, “Zur Pilzkunde Vorarlbergs," Österreichische Botanische Zeitschrift, vol. 53, no. 4, pp. 159-164, 1903.

[35] A. Lapeva-Gjonova and S. Santamaria, "First record of Laboulbeniales (Ascomycota) on ants (Hymenoptera: Formicidae) in Bulgaria," Zoonotes, vol. 22, pp. 1-6, 2011.

[36] K. Bezděčková and P. Bezděčka, "First records of the myrmecophilous fungus Rickia wasmannii (Ascomycetes: Laboulbeniales) in the Czech Republic," Acta Musei Moraviae, Sintiae Biologicae (Brno), vol. 96, pp. 193-197, 2011.

[37] S. Santamaria, "El orden Laboulbeniales (Fungi, Ascomycotina) en la Península Ibérica e Islas Baleares," Edicions especials de la Societat Catalana de Micologia, vol. 3, pp. 1-396, 1989.

[38] F. Cavara, "Di una nuova Laboulbeniacea, Rickia wasmannii, nov. gen. et nov. spec.," Revue Mycologique, vol. 22, pp. 155$156,1899$.

[39] A. Tartally, B. Szúcs, and J. R. Ebsen, "The first records of Rickia wasmannii Cavara, 1899, a myrmecophilous fungus, and its Myrmica Latreille, 1804 host ants in Hungary and Romania (Ascomycetes: Laboulbeniales; Formicidae)," Myrmecological News, vol. 10, p. 123, 2007.

[40] C. Spegazzini, "Primo contributo alla conoscenza delle Laboulbeniali italiani," Redia, vol. 10, pp. 21-75, 1914.

[41] L. Huldén, "Floristic notes on Palaearctic Laboulbeniales (Ascomycetes)," Karstenia, vol. 25, pp. 1-16, 1985.

[42] P. Bezděčka and K. Bezděčková, "First record of the myrmecophilous fungus Rickia wasmannii (Ascomycetes: Laboulbeniales) in Slovakia," Folia Faunistica Slovaca, vol. 16, pp. 77-78, 2011.

[43] X. Espadaler and D. Suñer, "Additional records of Iberian parasitic insect fungi: Laboulbeniales (Ascomycotina) and Aegeritella (Deuteromycotina)," Orsis, vol. 4, pp. 145-149, 1989.

[44] R. Baumgartner, "A propos de quelques Laboulbéniales (champignons sur insectes)," Mitteilungen der Naturforschenden Gesellschaft in Bern, vol. 1930, pp. 62-65, 1931.

[45] J. Pontin, Ants of Surrey, Surrey Wildlife Trust, United Kingdom, 2005.

[46] "Sifolinia's Ant Blog. Rickia wasmannii in the UK," 2011, http://sifolinia.blogspot.com/2009/10/rickia-wasmannii-inuk.html.

[47] X. Espadaler and N. Lodos, "Camponotus baldaccii Emery (Hym., Formicidae) parasitized by Laboulbenia camponoti Batra (Ascomycetes) in Turkey," Turkish Journal of Plant Protection, vol. 7, pp. 217-219, 1983.
[48] J. Balazuc, X. Espadaler, and J. Girbal, "Laboulbenials (Ascomicets) ibèriques," Collectanea Botanica, vol. 13, pp. 403421, 1982.

[49] X. Espadaler and J. Blasco, "Laboulbenia camponoti Batra, 1963 (Fungi, Ascomycotina) en Aragón,” Mallada, vol. 2, pp. 75-80, 1991.

[50] W. W. Judd and R. K. Benjamin, "The ant Lasius alienus parasitized by the fungus Laboulbenia formicarum Thaxter at London, Ontario," Canadian Entomologist, vol. 90, p. 419, 1958.

[51] M. R. Smith, "Remarks concerning the distribution and hosts of the parasitic ant fungus, Laboulbenia formicarum Thaxter," Bulletin of the Brooklyn Entomological Society, vol. 23, pp. 104106, 1928.

[52] A. C. Cole Jr., "Laboulbenia formicarum Thaxter, a fungus infesting some Idaho ants, and a list of its known North American hosts (Hym.: Formicidae)," Entomological News, vol. 46, p. 24, 1935.

[53] A. C. Cole Jr., "New ant hosts of the fungus Laboulbenia formicarum Thaxter," Entomological News, vol. 60, p. 17, 1949.

[54] M. R. Smith, "Ant hosts of the fungus, Laboulbenia formicarum Thaxter," Proceedings of the Entomological Society of Washington, vol. 48, pp. 29-31, 1946.

[55] R. Thaxter, "Preliminary diagnoses of new species of Laboulbeniaceae," Proceedings of the American Academy of Arts and Sciences of Boston, vol. 38, pp. 7-57, 1902.

[56] J. Bequaert, "A new host of Laboulbenia formicarum Thaxter, with remarks on the fungous parasites of ants," Bulletin of the Brooklyn Entomological Society, vol. 15, pp. 71-79, 1920.

[57] M. R. Smith, "An infestation of Lasius niger L. var. americana with Laboulbenia formicarum Thaxter," Journal of Economic Entomology, vol. 10, p. 447, 1917.

[58] T. P. Nuhn and C. G. Van Dyke, "Laboulbenia formicarum Thaxter (Ascomycotina: Laboulbeniales) on ants (Hymenoptera: Formicidae) in Raleigh, North Carolina with a new host record," Proceedings of the Entomological Society of Washington, vol. 81, pp. 101-104, 1979.

[59] W. M. Wheeler, "Colonies of ants (Lasius neoniger Emery) infested with Laboulbenia formicarum Thaxter," Psyche (Cambridge), vol. 17, pp. 83-86, 1910.

[60] M. R. Smith, "Another ant genus host of the parasitic fungus Laboulbenia Robin (Hymenoptera: Formicidae," Proceedings of the Entomological Society of Washington, vol. 63, p. 58, 1961.

[61] X. Espadaler, C. Lebas, J. Wagenknecht, and S. Tragust, " $\mathrm{La}$ boulbenia formicarum (Ascomycota, Laboulbeniales) an exotic parasitic fungus, on an exotic ant in France," Vie et Milieu, vol. 61, pp. 41-44, 2011.

[62] X. Espadaler and S. Santamaria, "Laboulbenia formicarum crosses the Atlantic," Orsis, vol. 18, pp. 97-101, 2003.

[63] J. A. Herraiz and X. Espadaler, "Laboulbenia formicarum (Ascomycota, Laboulbeniales) reaches the Mediterranean," Sociobiology, vol. 50, no. 2, pp. 449-455, 2007.

[64] K. Hölldobler, "Über merkwürdige Parasiten von Solenopsis fugax," Zoologischer Anzeiger, vol. 70, pp. 333-334, 1927.

[65] K. Hölldobler, "über eine merkwürdige Parasitenerkrankung von ,Solenopsis fugax," Zeitschrift für Parasitenkunde, vol. 2, no. 1, pp. 67-72, 1929.

[66] K. Hölldobler, "Weitere Mitteilungen Über Haplosporidien in Ameisen," Zeitschrift für Parasitenkunde, vol. 6, no. 1, pp. 91100, 1933.

[67] S. R. Sanchez-Peña, A. Buschinger, and R. A. Humber, "Myrmicinosporidium durum, an enigmatic fungal parasite of ants," 
Journal of Invertebrate Pathology, vol. 61, no. 1, pp. 90-96, 1993.

[68] A. Buschinger and U. Winter, "Myrmicinosporidium durum Hölldobler 1933, Parasit bei Ameisen (Hym., Formicidae) in Frankreich, der Schweiz und Jugoslawien wieder aufgefunden," Zoologischer Anzeiger, vol. 210, pp. 393-398, 1983.

[69] A. Buschinger, J. Beibl, P. D'Ettorre, and W. Ehrhardt, "Recent records of Myrmicinosporidium durum Hölldobler, 1933, a fungal parasite of ants, with first record north of the Alps after 70 years," Myrmecologische Nachrichten, vol. 6, pp. 9-12, 2004.

[70] F. García and X. Espadaler, "Nuevos casos y hospedadores de Myrmicinosporidium durum Hölldobler, 1933 (Fungi)," Iberomyrmex, vol. 2, pp. 3-9, 2010.

[71] R. M. Pereira, "Occurrence of Myrmicinosporidium durum in red imported fire ant, Solenopsis invicta, and other new host ants in eastern United States," Journal of Invertebrate Pathology, vol. 86, no. 1-2, pp. 38-44, 2004.

[72] X. Espadaler, "Myrmicinosporidium sp., parasite interne des fourmis. Etude au MEB de la structure externe," in $L a$ Communication chez les sociétés d'insectes, A. De Haro and X. Espadaler, Eds., pp. 239-241, Colloque Internationale de l'Union Internationale pour l'Etude des Insectes Sociaux, Section française, Barcelona, Spain, 1982.

[73] O. Kanizsai, "Myrmicinosporidium durum, egy különös hangyapatogén," in Proceedings of the 3rd Carpathian Basin Myrmecological Symposium, p. 5, Senete, Romania, 2010.

[74] H. Donisthorpe, British Ants, Their Life-History and Classification, Brendon \& Son, Plymouth, UK, 1915.

[75] C. S. Moreau, C. D. Bell, R. Vila, S. B. Archibald, and N. E. Pierce, "Phylogeny of the ants: Diversification in the age of angiosperms," Science, vol. 312, no. 5770, pp. 101-104, 2006.

[76] S. G. Brady, T. R. Schultz, B. L. Fisher, and P. S. Ward, "Evaluating alternative hypotheses for the early evolution and diversification of ants," Proceedings of the National Academy of Sciences of the United States of America, vol. 103, no. 48, pp. 18172-18177, 2006. 

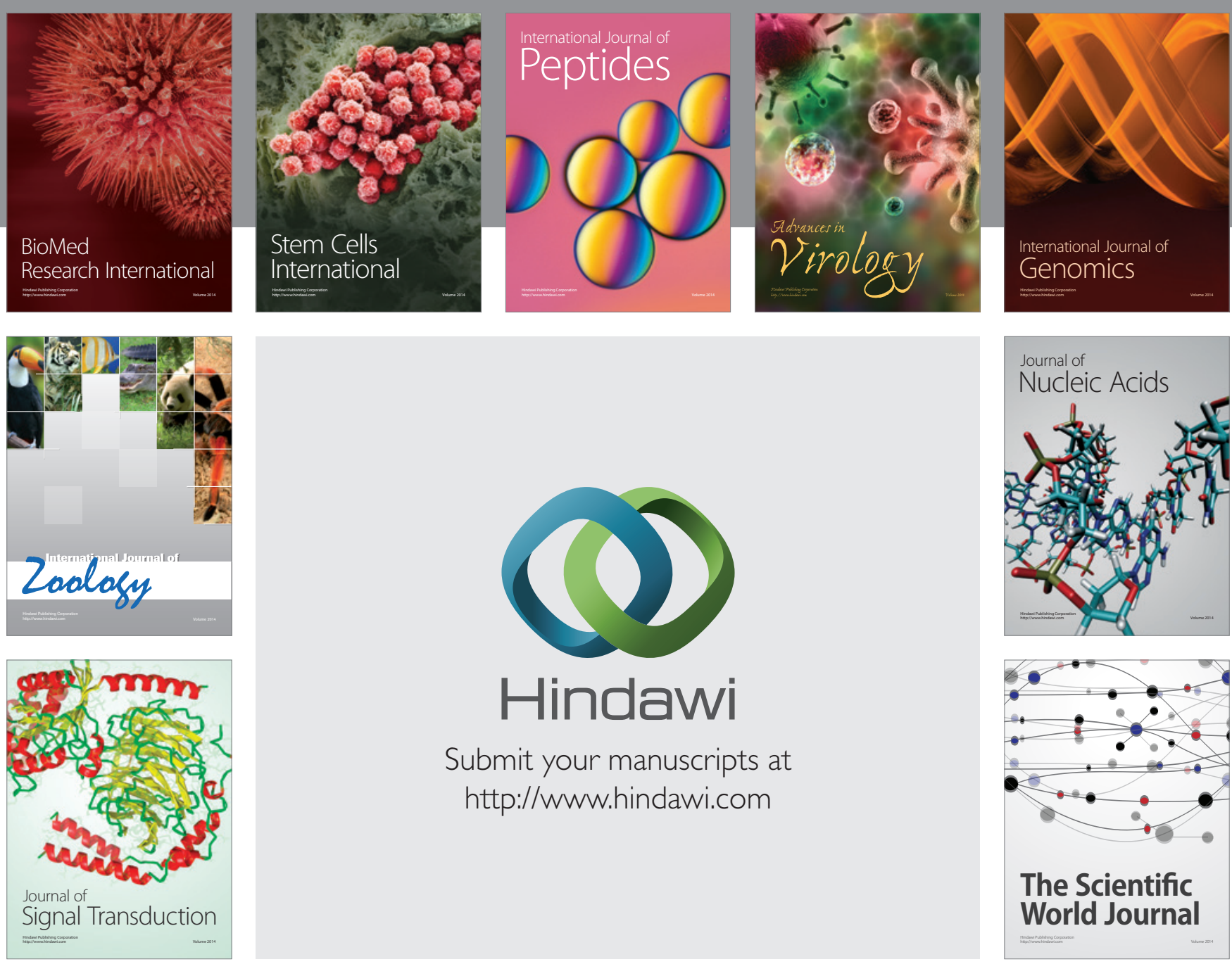

Submit your manuscripts at

http://www.hindawi.com
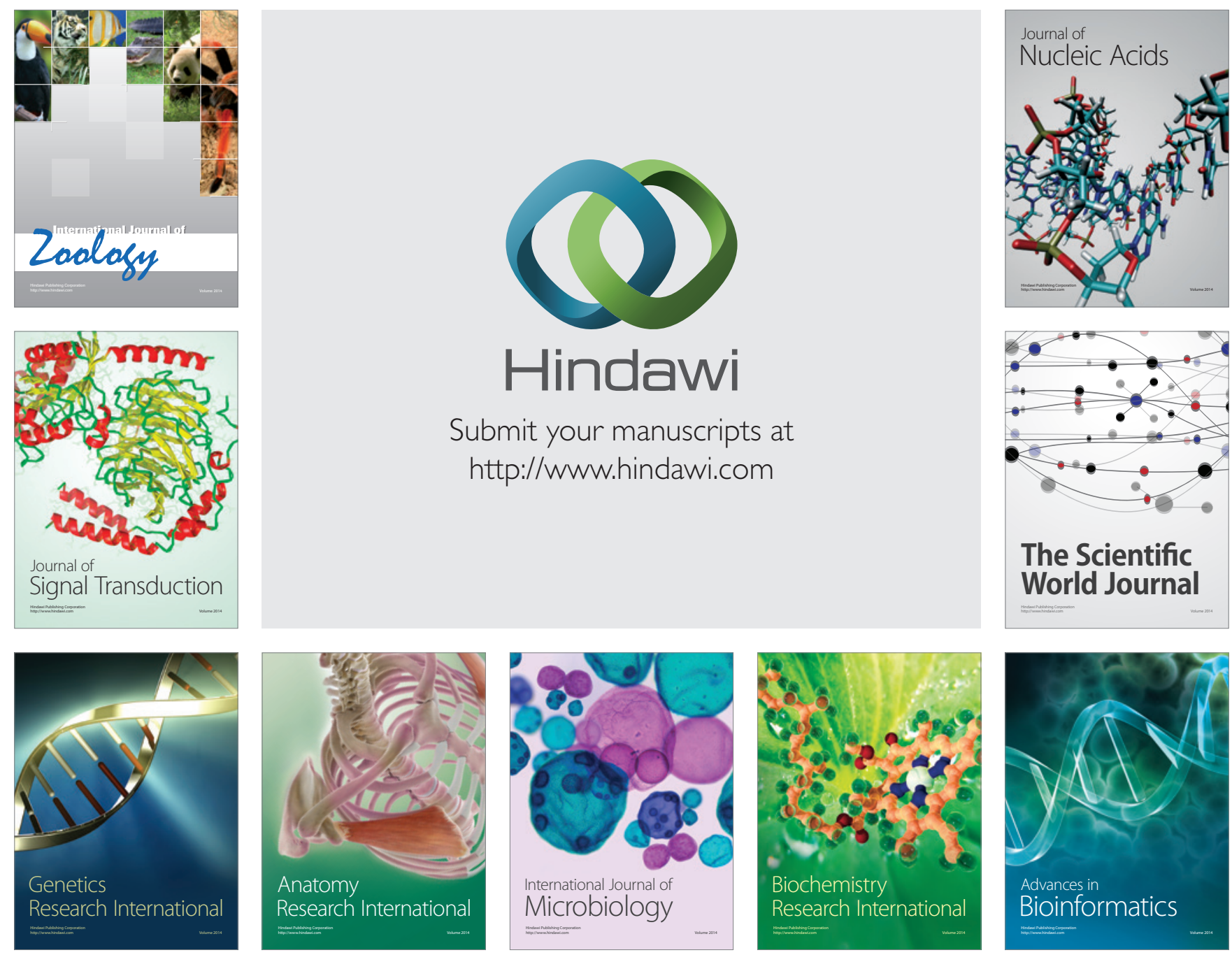

The Scientific World Journal
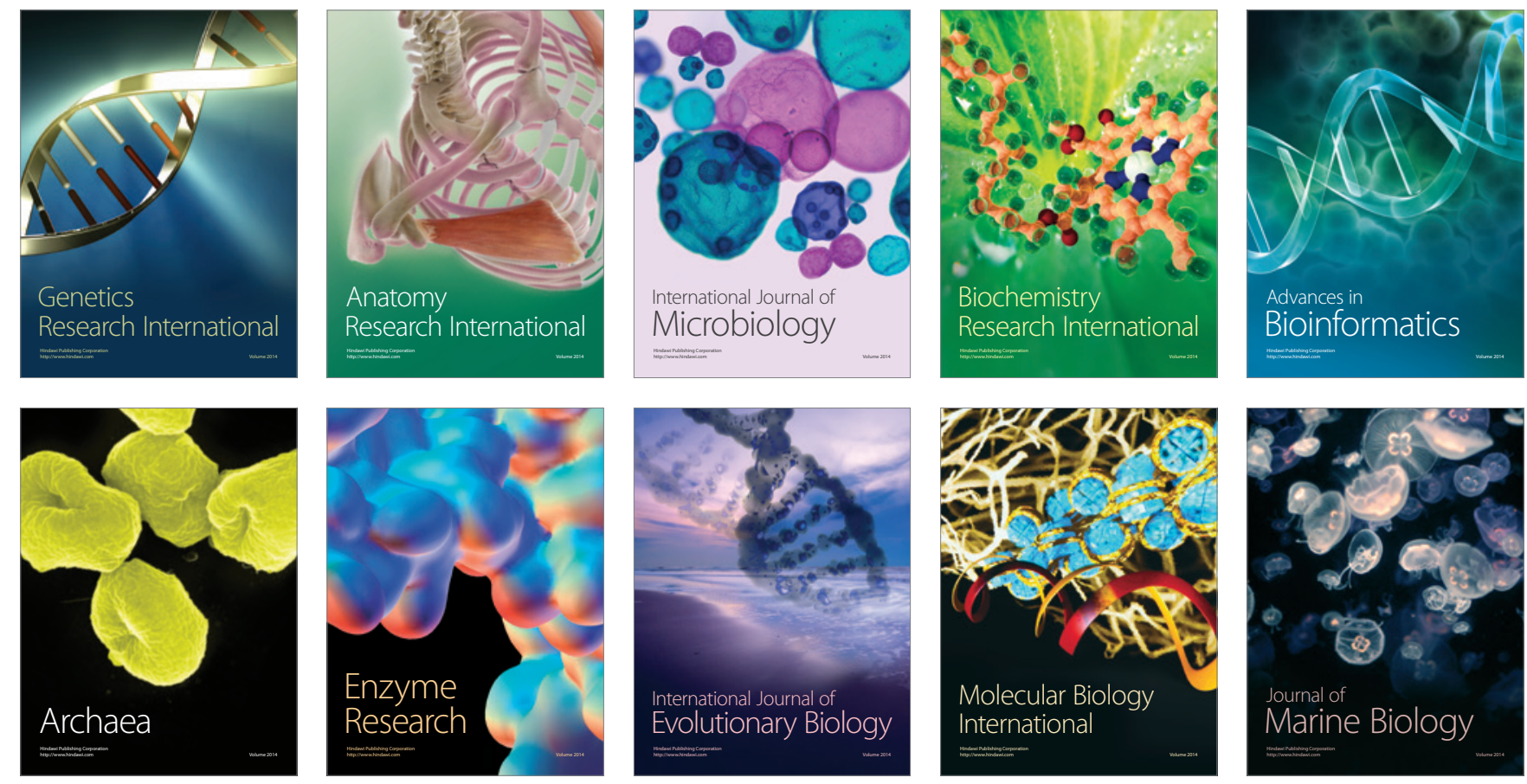